\title{
Major Matters: A Comparison of the Within-Major Gender Pay Gap across College Majors for Early-Career Graduates
}

\author{
LAURIE A. MORGAN*
}

I use data from the 1993 National Survey of College Graduates and appended 1990 Census on about 11,000 men and women college graduates (8400 with bachelor's degrees only, and 2800 with graduate degrees) who earned degrees in a 5-year period (1984-1988), to address questions regarding the link between college major and early-career gender pay differentials. I look at within-major gender pay differentials for two groups of college graduates: those whose highest degrees are bachelor's and those who hold graduate degrees. Among those whose highest degrees are bachelor's, I find that within-major gender pay penalties are virtually zero for professional majors. Gender pay penalties are large for general studies majors: social sciences, history, and humanities, and business administration (except accounting). For these, jobs account for a large portion of the unexplained gap. Among individuals who hold graduate degrees, I find that within-major gender pay penalties are zero for all fields. My findings suggest that pay penalties to women in the aggregate can be traced to relatively large penalties in a couple of key fields (bachelor's degree-level general studies fields): social sciences and humanities, and business administration (except accounting). These findings are important, as they contradict the prevailing view. Existing empirical research suggests that women are uniformly disadvantaged compared to men regardless of field of study and, thus, field of study explains little or none of the gender gap in pay. I conclude that supply-side mechanisms are important factors in producing gender inequality among college graduates, and suggest that we further focus our attention on the "supply side" in understanding segregation and gender pay inequality.

\section{Introduction}

AMONG COLLEGE GRADUATES, THE RELATIONSHIP BETWEEN COLLEGE MAJORS and pay stands at the interface of women's choices and the labor market, or

* Ross School of Business, University of Michigan, 701 Tappan, Ann Arbor, MI 48104, USA. E-mail: morganla@umich.edu

Industrial Relations, Vol. 47, No. 4 (October 2008). (C) 2008 Regents of the University of California Published by Blackwell Publishing, Inc., 350 Main Street, Malden, MA 02148, USA, and 9600 Garsington Road, Oxford, OX4 2DQ, UK. 


\section{6 / LaUrie A. Morgan}

what are often characterized as supply- and demand-side processes (Reskin 1993). ${ }^{1}$ Women have made tremendous gains in earning degrees in many traditionally male majors. The question is: will these gains translate to narrowing the gender pay gap?

The link between college majors and pay seems obvious. The view that gender differences in schooling plays a central role in defining gender differences in pay underpins much of the research on gender and education (American Association of University Women 1991; Greenberger 2002; Marini and Brinton 1984), as well as efforts to encourage women (and to some extent, men) to enter nontraditional majors. Marcia Greenberger, in her testimony before the 2002 Senate subcommittee on "Science, Technology and Space," quoted from former U.S. Representative Patsy Mink: "Discrimination against women in higher education is one of the most damaging forms of prejudice for our nation for it deprives a high proportion of our people of the opportunity for equal employment and equal participation in national leadership" (2002).

In particular, women's absence from traditionally male majors, primarily science, math, and engineering (SME), has been highly problematized and publicized, and has even gained Congressional attention (Congressional Commission on the Advancement of Women and Minorities in Science, Engineering and Technology Development; U.S. Congress 2000). The National Science Foundation along with several private foundations fund many programs designed (1) to understand why women's entry into SME has been so slow, and (2) to support programmatic efforts encouraging girls and women to pursue SME studies and degrees. ${ }^{2}$ At the same time there is excitement that women have achieved near parity with men in graduation from law and medical schools (Women's Bureau, U.S. Department of Labor 1993).

While it seems intuitive that closing the gap in college majors is a necessary condition for pay equality, the question is, is it sufficient? The role of college major in producing pay inequality may not be so straightforward if, for example, women who do earn college degrees in the higher-paying, traditionally male fields do not earn the same pay as men in those fields because of job segregation, where women work in lower-paying occupations and establishments

\footnotetext{
1 "When people say that they are pursuing their chosen field, they may well be right, but there is also a good chance that social factors played a large role in leading them to feel that this was the right choice for them" Jacobs (2001: 547). See also, England (1992: 18-20) for a discussion of framing this as a question of women's choices.

${ }^{2}$ At the National Science Foundation, these include "Increasing the Participation and Advancement of Women in Academic Science and Engineering Careers" (ADVANCE), and the "Program of Gender Equity in Science, Mathematics, Engineering and Technology" (PGE).
} 
than similarly trained men. Thus, a better understanding of the mechanism through which college education is connected to gender pay inequality will influence where efforts to address pay inequality should be focused - on the educational process (or other prelabor market processes), or on employers.

This study contributes to our understanding of the linkages between gender differences in education and pay inequality in several important ways. First, I focus on within-field gender pay differentials across groups of related majors. Existing research on the relationship between field of study and gender pay inequality has focused on the extent to which gender differences in field of study (or sex segregation in majors) explains pay inequality overall (e.g., Brown and Corcoran 1997; Marini and Fan 1997). While this is an important line of inquiry, the central issue is the question of whether women earn the same pay as men in the same majors/fields of study, especially traditionally male fields, which is a matter of within-field gender pay differentials. I compute and compare these within-field gender pay differentials across fields of study, including "engineering and architecture," and "mathematical, physical, and computer sciences." No other studies assess within-field differentials among college graduates directly. ${ }^{3}$ Furthermore, most studies of women professionals are case studies, making comparisons in outcomes across fields difficult, if not impossible because of data and methodological differences.

Second, these analyses are possible only with data that cover women and men in a broad range of fields, even those where they are underrepresented. I use data from the 1993 National Survey of College Graduates (NSCG) (National Science Foundation 1993), which oversampled scientists and engineers, particularly women. These analyses cover approximately 11,200 individuals: 8400 whose highest degrees are bachelor's, and 2800 who hold graduate degrees. The bachelor's degree data include 2205 individuals with majors in engineering (363 of whom are women) and 1306 in mathematics, computer, or physical sciences (496 of whom are women). The graduate degree data include 854 individuals in engineering and architecture, and mathematics, computer, and physical sciences (178 of whom are women). Because of data limitations, few other studies are able to make meaningful comparisons across such a wide range of fields. For example, the widely used, nationally representative data sets (e.g., the Panel Study of Income Dynamics or the National Longitudinal Study of Youth) include few, if any, women with college degrees in engineering or in the mathematical, physical, or computer sciences.

\footnotetext{
${ }^{3}$ Existing research is either silent on the question of whether the gender pay differentials are consistent across fields of study (e.g., Marini and Fan 1997), or analyze the related, but not equivalent, issue of differences in within-gender payoffs to specific majors/content (e.g., Daymont and Andrisani 1984).
} 


\section{8 / Laurie A. Morgan}

The third important contribution of this study derives from its focus on college graduates. We have no reason to expect that high school course concentration (for example, taking several math classes) is linked to pay in the same way as college major, and empirical research supports this view (Brown and Corcoran 1997). To the extent the linkages between the college majors and pay among college graduates are tighter than those between course concentration and pay among high school graduates, aggregating across educational levels (for example, less than high school, high school, some college, college graduate) will underestimate the role of majors in accounting for pay differences among college graduates.

Finally, while a better understanding of the relationships between supply and demand processes in producing gender inequality among college graduates may shed light on barriers faced by women in the broader labor force, these women are important in their own right. They comprise a substantial portion of the paid labor force; as of 2002, 31 percent of women over the age of 25 in the civilian paid labor force held a bachelor's degree or higher, as compared to 32 percent of men (U.S. Census Bureau 2002), and their share is increasing over time as younger cohorts of women earn college degrees at higher rates than older cohorts, and at higher rates than men. Women have earned more bachelor's degrees than men since 19811982, and more master's degrees than men since 1980-1981; as of 20002001, women earned 57 percent of bachelor's degrees, 59 percent of master's degrees, although they continue to lag behind men in more advanced degrees with 47 percent of professional degrees, and 44 percent of doctoral degrees (National Center for Education Statistics 2003, Table 246). In addition, women college graduates are different from the average woman worker. Historically, they have participated at higher rates and have had higher labor force attachment than other women; Blau, Ferber, and Winkler (2002: 118, Table 1a) report that, in 1995, the average participation rate for women with more than 16 years of education was 82.8 percent (comparable men participate at 93.8 percent), compared to 68.9 percent for women with 12 years of education (86.9 percent for men). Over the period 1969-1994, women with more than 16 years of education have made the largest gains in terms of percentage increases in real weekly wages of any education group - a 20 percent increase, compared to losses for men in all educational groups (Blau et al. 2002: 130, Table 5).

My objective is to contribute to the ongoing discussion about the relative importance of supply-side versus demand-side processes in producing gender pay inequality. If women, compared to men with similar levels of education, are discriminated against in the labor force, we expect women's assignment to lower-paying jobs (both occupations and employers) will 
account for residual differences (Petersen and Morgan 1995). To the extent women earn similar rewards to men for college majors, changing women's (and/or men's) distribution on college majors would be expected to produce dramatic gains in pay. This would focus our attention on women's choices of college majors, a line of research and policy interest well under way. If, however, women migrate to lower-paying jobs than similarly trained men in spite of similar educations, this focuses our attention on posteducational and labor market processes, including employer discrimination. ${ }^{4}$

\section{Segregation in College Majors}

Numerous studies have documented patterns of sex segregation in college majors. Women have earned more bachelor's and master's degrees than men for some time, and overall segregation indices, a measure of the proportion of women (or men), who would have to change majors in order to be similarly distributed across majors (at the bachelor's degree level), have decreased from 46 percent in 1972 (Jacobs 1989, Table 6.2; 24 fields) to 29.4 percent in 1990 (Jacobs 1995, Table 87; 24 fields). ${ }^{5}$ Most of those gains were made before the mid-1980s, and resulted in large part from women's movement into traditionally male fields (not from men's movement into traditionally female fields) (Jacobs 1995: 91), although gains have resulted as well from relative growth in integrated fields, like business administration, especially in the latter part (post mid-1980s) of this period (Jacobs 1995: 86). At the master's/professional level, the segregation index declined from 43 percent in 1980 to 38 percent in 1990, and at the doctoral level actually increased from 32.2 to 36.2 percent between 1980 and 1990 (Jacobs 1995, Table 1). According to Jacobs (1995: 87), this is a result of growth of segregated fields: "had the relative size of fields remained constant, there would have been a continued decline in segregation among recipients of master's and professional degrees throughout the 1980s." 6

While segregation indices tell an important part of this story, as summary measures they may mask some important trends. Women have made dramatic increases in shares of bachelor's degrees in several traditionally male majors, as well as in key professional majors of medicine, law, and business. Between 1970-1971 and 2000-2001, the proportion of bachelor's degrees awarded to

\footnotetext{
${ }^{4}$ Of course, posteducational supply-side processes may play a role as well, for example, women's ongoing labor supply decisions.

${ }^{5}$ Author's computation of 24-field D for 1999-2000 is 27.1, based on data from the National Center for Education Statistics (2003, Table 266).

${ }^{6}$ See also England and Li (2006).
} 


\section{0 / LaUrie A. Morgan}

women increased from 9 to 50 percent in business administration, 14 to 41 percent in physical sciences, ${ }^{7}$ and 38 to 48 percent in mathematics. Although great progress has been made in engineering, where women's share of bachelor's degrees has increased from less than 1 percent to 18 percent, and computer sciences where the increase has been from 13 percent to 26 percent, the substantial imbalance in these lucrative fields remains a serious concern as is men's absence from traditionally female fields of teaching and nursing. As of 2000-2001, men comprised 25 percent of bachelor's degree recipients in education (as compared to 23 percent in 1970-1971). At the professional degree level, women have reached near parity with men in medicine, law, and business. Over the period from 1970-1971 to 2000-2001, women's share grew from 9 to 43 percent of medical degrees, from 7 to 47 percent of law degrees, and from 4 to 45 percent of master's degrees in business administration. ${ }^{8}$

Theories explaining the uneven distribution of women and men in college majors are wide ranging (see Marini and Brinton 1984 for a review) and focus primarily on girls' absence from traditionally male fields. ${ }^{9}$ Most can be understood as operating under a broad umbrella of gender socializationthe creation of preferences for appropriately masculine or feminine workbut attention has been given various of its mechanisms, including expectations about future family/career trade-offs (Polachek 1979; but see England et al. 1988 for counterevidence), discouragement from active classroom participation (Sadker and Sadker 1994; but see Kleinfeld 1998), and biased evaluation (Valian 1998).

Of course, most of these explanations are hard-pressed to account for the dramatic, if somewhat uneven, changes in women's college majors that have occurred over the last 30 years. While the "math problem" is usually characterized as women's entry into SME, women have reached almost 50 percent representation in math and physical science graduates (although they comprise 56 percent of all graduates), but not in engineering. Perhaps the

\footnotetext{
${ }^{7}$ The representation of women in physical sciences bachelor's degree graduates is particularly noteworthy as it increased to 41 percent in 2000-2001 from 32 percent in 1990-1991 (author's computations from the National Center for Education Statistics, 2003, Table 291).

${ }^{8}$ As with women's representation in the physical sciences, women's share of MBA degrees increased considerably over the period $1990-1991$ to $2000-2001$, from 35 to 45 percent, again, quite a large increase in just a 10-year period (author's computations from the National Center for Education Statistics, 2003, Table 280).

${ }^{9}$ The emphasis on girls derives from an interest in ensuring that girls have access to the same educational opportunities as boys, particularly to educational opportunities that are expected to lead to higher-paying jobs/careers (see, for example, Greenberger 2002). Of course, men's and boys' access to traditionally female majors is of interest as well, although efforts to attract men to these fields may be motivated more by a desire to increase the stature of the profession than to enhance men's occupational outcomes (see, e.g., Williams 1989 for a discussion of the nursing profession's efforts to attract men).
} 
most promising explanation is that as formal barriers are removed, women take advantage of new opportunities (Kessler-Harris 1982), which suggests that further attention be directed to the legal and institutional environments, as well as various programmatic efforts, in understanding these very encouraging trends.

In questioning the link between majors and occupations, I take degree major as indicative of women's preferences (as shaped and constrained by social, educational, and other institutions) at the point of labor market entry. These preferences ultimately play out in the labor force, where employers play a central role, and where women may face additional barriers.

\section{Existing Research on College Majors and the Gender Pay Gap}

Research addressing the mechanism through which sex segregation in college majors is related to the gender pay gap is surprisingly sparse. Yet the question of why women are disproportionately concentrated in lower-paying jobs than men has been identified as a substantial key to understanding (and hopefully correcting) the gender pay gap. Job segregation by sex is the primary cause of the gender pay gap. Women and men earn the same wages when they are in the same jobs; the problem is that they rarely share the same jobs (Petersen and Morgan 1995). However, most analyses of the relationship between job segregation and gender pay differentials take as their starting point the distribution of employed men and women on (different) jobs, and make no attempt to address the sources of these patterns (e.g., Bielby and Baron 1984; Petersen and Morgan 1995). On the other hand, studies addressing the trends in the gender wage gap over time usually operationalize education only as "amount" - either years or highest degree level (e.g., Blau 1998; Wellington 1993).

In the labor force overall, level of education is related to earnings (Stoops 2004), but because men and women have similar amounts of education, it does not explain gender wage differences (Corcoran and Duncan 1979). Differences in women's versus men's distribution on college majors or educational content explain a portion of the wage gap between male and female college graduates (Brown and Corcoran 1997; Daymont and Andrisani 1984; Paglin and Rufolo 1990), although the size of estimates varies across studies because of differences in which workers are studied and differences in modeling and model estimation techniques employed. ${ }^{10}$ Furthermore, both Daymont and Andrisani (1984) and Paglin and Rufolo (1990) report

\footnotetext{
${ }^{10}$ Brown and Corcoran (1997) cover a cross-section of the labor force; Daymont and Andrisani (1984) focus on recent college graduates; Paglin and Rufolo (1990) analyze starting salaries of college graduates.
} 


\section{2 / Laurie A. Morgan}

significant within-gender differences in the returns to at least some traditionally male fields, and conclude that lower payoffs in these fields may dampen women's interest in them.

In all of these studies, the key mechanism through which majors operate is theorized to be the production of, or relationship to, job-specific human capital - different types of educational content produce different skills, which in turn have different wages in the labor market. In only a few studies has the mechanism for the education-pay linkage been elaborated by explicitly acknowledging the intervening role of jobs. The exception is Marini and Fan (1997), who argue that wages attach to jobs, and estimate a model to measure the relative contribution of human capital factors, including field of study, family background, and career aspirations, as compared to occupations and employer characteristics. Focusing on gender pay differentials at career entry, they find that differences in field of study account for little of the gender earnings gap at career entry, but that occupation and employer characteristics account for much of the gap not explained by education. However, Marini and Fan (1997) analyze data pooled across a wide range of educational levels. Although they control for the interaction between amount of education and four categories of field of study, their sample is comprised mostly of individuals who have less than 16 years of education (Marini and Fan (1997) use years of education rather than degree completion). Only 22 percent of the sample has 16 years or more, and we expect even fewer who have actually completed a college bachelor's degree or graduate degree in that time period. Given Brown and Corcoran's (1997) finding that educational content accounts for little of the gender pay gap between high school graduates and those with some college but no degree, it is not surprising that education does not explain much of the gap in Marini and Fan's sample (1997).

Finally, Joy (2000) directly addresses occupational differences at career entry and finds that women move to lower-paying occupations than men, even among similar majors. Using a sample from the Baccalaureate and Beyond Longitudinal Study 93/94, she finds that women are more likely to take first jobs in clerical occupations regardless of major. However, it is unclear whether this was based on data aggregated across majors or simply controlling for major, in which case outcomes for women in liberal arts, education, and business majors will dominate findings.

\section{Question and Hypotheses}

My aim is to address the overarching question of the extent to which gender pay differentials among college graduates are a matter of differences 
in the distribution of men and women on college majors as opposed to gender pay inequality within college majors. I argue that we should think about college major as logically prior to jobs for college graduates, and so these findings should inform the broader discussion about how much of the pay penalty to college-educated women is a matter of prelabor market, supply-side processes, including the choice of college major, versus postgraduate labor market processes, including employer discrimination. I consider the following hypotheses.

$H_{1}$ : Prelabor market, supply-side explanation:

(a) Within-major pay penalties to women are small.

(b) Because women are concentrated in lower-paying majors, major explains overall gender pay gap.

Even if college majors were not segregated by gender, various theories suggest that pay inequality would be produced in the labor market through employer discrimination, re-sorting women into lower-paying occupations and establishments than men. While formulations vary in the specifics, many, including neoclassical theories, predict that employers will discriminate against women to the extent that the costs of doing so are not prohibitive (England 1992). Mechanisms through which costs accrue to discriminators are (1) competitive pressures, ${ }^{11}$ (2) enforcement of laws prohibiting such actions, through application of fines and other penalties (see, for example, Petersen and Saporta 2004), and (3) pressures from key constituents in firms' institutional environments (for a discussion as it applies to race, see Collins 1997). Alternatively, Reskin (2000) argues that the mechanism, or "proximal cause," of sex segregation is not intentional discrimination, but cognitive bias, where employers unintentionally draw on unconscious stereotypes of women and men in making hiring decisions. In either case, the result is the same: women are assigned to different, and lower-paying, jobs - both lower-paying occupations and lower-paying employers-than men. ${ }^{12}$

Finally, while most theories predict that women will be disadvantaged in all occupations (for example, even in nursing; Williams 1989), several, most notably Kanter's (1977) tokenism theory, suggest that predominately male

\footnotetext{
${ }^{11}$ Under perfect competition, employers cannot afford to indulge tastes for discrimination, and errors in expectations that drive statistical discrimination will be diminished as those making erroneous assumptions will be driven out of business, but see England (1992) for a nuanced discussion of statistical discrimination that can persist.

${ }^{12}$ For a comprehensive discussion of the role of jobs in accounting for gender pay inequality, see Petersen and Morgan (1995).
} 


\section{4 / Laurie A. Morgan}

professions and occupations will be especially impervious to women's entry and progress.

From these lines of theorizing, I derive the following:

$\mathrm{H}_{2}$ : Labor market, demand-side explanation:

(a) Within-major pay penalties are large, and are explained by jobs.

(b) Majors do not explain the overall gender pay gap; jobs do.

To Hypotheses 1 and 2, I offer a third, hybrid, view. I suggest that the supply-side explanation will hold in some cases; the demand-side explanation will hold in others. Supply-side processes will hold for women in professional majors; that is, women will do best in majors and with degrees that in some sense define jobs or establish their qualifications for and interest in these jobs (professional bachelor's degree majors and graduate degrees). I argue that this pattern is predicted by both neoclassical and cognitive bias models. For the neoclassical models, and considering the formulation of Petersen and Saporta (2004), discrimination against women with well-defined credentials may be more costly than against other women. First, it should heighten the visibility of jobs discrepancies to the women themselves, who probably have a clear sense of the kinds of positions for which they are qualified, which may increase risk, and therefore cost, of fines and litigation. Second, it should heighten the visibility of discrimination to other constituencies, both internal and external to the organization, in the organization's institutional environment, to whom employers want to appear to be fair-minded. For example, I theorize that it is much easier to assign a woman with a sociology degree to the position "administrative assistant" (secretary), than it would be to assign a woman with an engineering degree to that position.

Furthermore, this is consistent with a cognitive bias mechanism described by Reskin (2000). I argue that the operation of unconscious stereotyping should be much less vigorous where employers face women with specific credentials, like professional degrees. Reskin (2000) argues that one way to mitigate the operation of cognitive bias is to use objective data as the basis of evaluation; surely college major is one such piece of information. On the other hand, I suggest that a general studies college major provides no such information, and employers' stereotypes about women's suitability and interests for specific jobs (traditionally female jobs) would be expected to prevail.

\section{$H_{3}:$ Combination:}

(a) The supply-side explanation will hold for graduate degrees and professional bachelor's degree majors, since those have a tighter link to specific 
jobs. The demand-side explanation will hold for bachelor's degree majors less tightly linked to specific jobs-bachelor liberal arts and business degrees.

(b) College majors will explain a portion of the overall gender pay gap; jobs will explain a portion of the unaccounted-for gap.

In all cases I am interested in describing and explaining pay differentials; I do not address the question of why women and men are differently distributed across majors, but rather the pay outcome implications of the distributions that exist.

I limit these analyses to early career outcomes, defined as having graduated from college (with a bachelor's, master's, professional, or doctoral degree) in the 5-year period after 1983 and before 1989, for several reasons. First, including a broad cross-section necessarily aggregates across cohorts as well as life cycle and career stages. Linkages between major and career may be weaker for those in later life cycle and career stages, or for those of older cohorts, who may have faced a much different institutional environment as compared to women whose careers have begun more recently, so that aggregating across these groups may obscure patterns for younger cohorts of women. Furthermore, early career outcomes could be considered a ceiling on payoff to major. If women start out at a disadvantage, we do not expect that they will catch up; rather, they will simply fall further behind. The final reason for limiting the study to an early career time frame is that several key studies, most notably Marini and Fan (1997), focus on career entry primarily for the reasons just discussed.

\section{Data and Method}

Data. Data are from the 1993 NSCG, conducted by the Bureau of Census for the National Science Foundation (1993). The 1993 NSCG is a survey of all college graduates; its sample is drawn from individuals identified in the 1990 Census as holding a bachelor's or higher college degree. For each individual in the NSCG, his or her 1990 Census data is appended. The NSCG (stratified random) sample was drawn from 1990 Census long form respondents who indicated they held at least one college degree at the bachelor's level or higher. The response rate was 80 percent (weighted). In these analyses, I include all individuals (1) who graduated from college with a bachelor's, master's, professional, or doctoral degree in the 5-year period after 1983 and before 1989; (2) for whom no data relevant to these analyses are missing or imputed (in either the 1993 NSCG or 1990 


\section{6 / Laurie A. Morgan}

Census); (3) who worked more than half of 1989 (more than 26 weeks), and usually worked 20 hours/week or more in 1989; (4) who graduated from U.S. institutions; (5) who are not self-employed, since earned income and return to capital are comingled for many of the self-employed, making pay data unreliable; and (6) whose equivalent hourly wage (calculated as weekly earnings divided by hours usually worked per week) is greater than $\$ 5$ per hour, since cases at less than this may be unreliable. Finally, in order to draw inferences about early career outcomes, I include only individuals who were younger than 40 years at the time their highest degree was awarded.

Table 1 contains selected descriptive statistics. Overall gender differences in pay are unmistakable. In the following, I first take up the question of withinfield gender pay differentials, and second address the question of the extent to which field of study accounts for these patterns overall.

These data are uniquely well suited to the study of gender pay differentials among college graduates. First, the NSCG contain highly detailed information about educational attainment: degree type, major field of study, and year of graduation for each degree. Furthermore, the NSCG not only includes graduates from all major degree fields, but also the sample is large enough to make meaningful comparisons across majors even for "early career" individuals as of the year of the survey (1990): 8439 individuals (3736 of whom are women) whose highest degree is a bachelor's; 2798 individuals (1190 of whom are women) who hold graduate degrees.

Similar analyses are not possible with other data sets. For example, the Panel Study of Income Dynamics and National Longitudinal Study of Youth, both commonly used to address questions regarding women and work, include relatively few women college graduates, and very few of these work in elite, traditionally male professions. In particular, they contain few women who have college degrees in the mathematical and physical sciences and in engineering. To conduct meaningful analyses on women in these fields, data collection must deliberately identify and oversample them. Neither are these analyses possible using Census data alone, since Census data do not contain detailed information on college major.

Although these data are cross-sectional rather than longitudinal, they can be used to shed light on the mechanism by which college major influences eventual occupation and ultimately pay, even if the distribution of women and men across college majors changes over time.

Estimating Pay Differentials and the Effects of Segregation. The following earnings equation is estimated using ordinary least-squares. It is estimated separately for those whose highest degrees are bachelor's, and those who hold graduate degrees. 
TABLE 1

Descriptive Statistics (Weighted)

1984-1988 Graduates; Data from the 1993 National Survey of College Graduates and Appended 1990 Census (Individuals Working 20 Hours/Week or More and More than 26 Weeks in 1989)

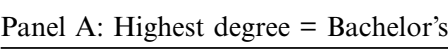

\begin{tabular}{|c|c|c|c|c|c|c|c|c|}
\hline & \multicolumn{4}{|c|}{ Overall } & \multicolumn{2}{|c|}{ Women } & \multicolumn{2}{|c|}{ Men } \\
\hline & Mean & (SD) & Minimum & Maximum & Mean & (SD) & Mean & (SD) \\
\hline 1989 weekly earnings (\$) & 532.99 & $(224.15)$ & 105.8 & 2249.8 & 487.6 & $(213.91)$ & 580.66 & $(224.79)$ \\
\hline Weeks worked, actual for 1989 & 50.1 & $(4.52)$ & 27 & 52 & 49.5 & $(5.09)$ & 50.7 & (3.74) \\
\hline Hours/week usually worked in 1989 & 42.8 & $(7.55)$ & 20 & 94 & 41.4 & $(7.02)$ & 44.3 & (7.79) \\
\hline Full-time work experience (years) & 4.3 & $(3.11)$ & 0.0 & 17.0 & 4.0 & $(2.94)$ & 4.7 & $(3.25)$ \\
\hline Part-time work experience (years) & 0.7 & $(1.54)$ & 0.0 & 7.0 & 0.7 & $(1.53)$ & 0.7 & $(1.56)$ \\
\hline \multicolumn{9}{|l|}{ Proportions with majors in: } \\
\hline Engineering and architecture & 0.126 & $(0.33)$ & & & 0.041 & $(0.20)$ & 0.217 & $(0.41)$ \\
\hline Math, computer, and physical sciences & 0.095 & $(0.29)$ & & & 0.065 & $(0.25)$ & 0.126 & $(0.33)$ \\
\hline Accounting & 0.083 & $(0.28)$ & & & 0.090 & $(0.29)$ & 0.076 & $(0.27)$ \\
\hline Business administration & 0.263 & $(0.44)$ & & & 0.246 & $(0.43)$ & 0.281 & $(0.45)$ \\
\hline Social sciences, history, and humanities & 0.252 & $(0.43)$ & & & 0.297 & $(0.46)$ & 0.204 & $(0.40)$ \\
\hline Nursing, health professions, and biological sciences & 0.106 & $(0.31)$ & & & 0.151 & $(0.36)$ & 0.059 & $(0.24)$ \\
\hline Education & 0.075 & $(0.26)$ & & & 0.111 & $(0.31)$ & 0.037 & $(0.19)$ \\
\hline$N$ (sample) & \multicolumn{2}{|c|}{8439} & & & \multicolumn{2}{|c|}{3736} & \multicolumn{2}{|c|}{4703} \\
\hline$N$ (weighted) & \multicolumn{2}{|c|}{$1,547,500$} & & & \multicolumn{2}{|c|}{792,600} & \multicolumn{2}{|c|}{754,900} \\
\hline
\end{tabular}


TABLE 1 (cont.)

Panel B: Highest degree $=$ Master's, Doctorate, or Professional

\begin{tabular}{|c|c|c|c|c|c|c|c|c|}
\hline & \multicolumn{4}{|c|}{ Overall } & \multicolumn{2}{|c|}{ Women } & \multicolumn{2}{|c|}{ Men } \\
\hline & Mean & (SD) & Minimum & Maximum & Mean & (SD) & Mean & (SD) \\
\hline 1989 weekly earnings (\$) & 573.9 & $(260.5)$ & 110.4 & 2884.6 & 531.4 & $(230.97)$ & 615.40 & $(280.20)$ \\
\hline Weeks worked, actual for 1989 & 48.8 & $(5.96)$ & 27 & 52 & 48.1 & $(6.13)$ & 49.4 & $(5.72)$ \\
\hline Hours/week usually worked in 1989 & 42.2 & $(9.63)$ & 20 & 96 & 41.2 & $(8.80)$ & 43.1 & $(10.30)$ \\
\hline Full-time work experience (years) & 4.3 & $(3.41)$ & 0.0 & 17.0 & 4.1 & $(3.31)$ & 4.5 & $(3.51)$ \\
\hline Part-time work experience (years) & 1.0 & $(1.71)$ & 0.0 & 8.0 & 0.9 & (1.63) & 1.0 & $(1.78)$ \\
\hline \multicolumn{9}{|l|}{ Proportions with majors in: } \\
\hline Traditionally male fields ${ }^{\mathrm{a}}$ & 0.170 & $(0.38)$ & & & 0.073 & $(0.26)$ & 0.265 & $(0.44)$ \\
\hline Professional fields ${ }^{\mathrm{b}}$ & 0.361 & $(0.48)$ & & & 0.280 & $(0.45)$ & 0.439 & $(0.50)$ \\
\hline Social sciences, history, and humanities & 0.181 & $(0.39)$ & & & 0.209 & $(0.41)$ & 0.154 & $(0.36)$ \\
\hline Traditionally female fields ${ }^{c}$ & 0.287 & $(0.45)$ & & & 0.436 & $(0.50)$ & 0.142 & $(0.35)$ \\
\hline$N$ (sample) & \multicolumn{2}{|c|}{2798} & & & \multicolumn{2}{|c|}{1190} & \multicolumn{2}{|c|}{1608} \\
\hline$N$ (weighted) & \multicolumn{2}{|c|}{432,950} & & & \multicolumn{2}{|c|}{213,850} & \multicolumn{2}{|c|}{219,100} \\
\hline
\end{tabular}

NoTES:

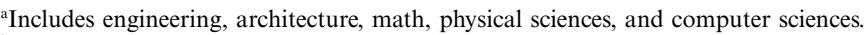

${ }^{b}$ Includes business (MBA), law (JD), and medicine (MD).

'Includes nursing, health, biological sciences, and education. 


$$
\begin{aligned}
\ln \left({\text { weekly earning } \left.s_{i}\right)=}\right. & \beta_{0}+\beta_{1}^{\prime} \text { Female }_{i}^{*} \text { Major field of study } y_{i} \\
& +\beta_{2}^{\prime} \text { Major field of study }_{i}+\beta_{3}^{\prime} \ln \left(\text { Hours }_{\text {week }}\right)_{i} \\
& +\beta_{4}^{\prime} \text { Experience }_{i}+\beta_{6}^{\prime} \text { Occupation }_{i}+\beta_{7}^{\prime} \text { Industry }_{i} \\
& +\beta_{8}^{\prime} \text { Organization }_{i}+\beta_{9}^{\prime} \text { Race }_{i}+\beta_{10} \text { Disabled }_{i} \\
& +\beta_{11} \text { Noncitizen }_{i}+\varepsilon_{i}
\end{aligned}
$$

This is of familiar form. The dependent variable is the natural log of weekly earnings in 1989, and is calculated as total earnings from employment, divided by actual weeks worked in 1989. It is logged in order to attenuate the effect of outliers, and for convenience in interpreting coefficients of dummy variables such as Female, where coefficients correspond roughly to a fractional bonus or penalty as compared to the omitted category (see Petersen 1989). For example, a coefficient of -0.05 on Female can be interpreted as approximately a 5 percent pay penalty for women as compared to men.

The coefficients of interest are those of the Female*Major field of study interaction terms (and of Female for analyses of overall versus within-major effects), as these are estimates of within-field effects of being female. I aggregate across related majors for estimation of these within-field effects in order to ensure adequate cases, both men and women, for estimation. For the bachelor's degree analyses, I use seven "fields": engineering and architecture; mathematics, physical, and computer sciences; accounting; business administration (except accounting); social sciences, history, and humanities; nursing, health, and biological sciences; and education. For the graduate degree analyses, I aggregate the estimates of effects of being female across groups of majors because of the smaller sample (and smaller numbers of men and women in nontraditional fields). Effects of being female are estimated for groups of fields: "traditionally male fields" (engineering and architecture, and mathematics, physical, and computer sciences); "professional fields" (business administration, law, and medicine); "social sciences, history, and humanities"; and "traditionally female fields" (nursing, health, biological sciences, and education). In the graduate degree analysis, I control for main effects of major field of study for the same categories as for the bachelor's degree analysis, except that I add controls for main effects of law, medicine, and business administration (which includes accounting). I do this because within these groups of related fields, women may be disproportionately concentrated in lower-paying majors. This means that, for example, effect of being female for "traditionally male fields" is with control for main effects of the three fields that comprise it: law, medicine, and business administration. I also estimated equations using the full set of detailed majors (more than 140 detailed majors), but this had no substantial effect on results. Therefore, I report results from the more parsimonious model. 
The overall model specification differs in form slightly from the standard analysis of gender pay differentials. I do this in order to directly estimate all within-field effects of being female in a single equation for each degree group (bachelor's and graduate). I include a full set of interaction terms between fields of study and "female"; for example, seven interactions for the bachelor's degree analysis and four interactions for the graduate degree analysis. The "omitted" category is one of the fields of study main effects, so for example I have a total of six "field of study" controls in the bachelor's degree analysis; the constant picks up earnings for the seventh, omitted field. In this scheme, each of the interactions is directly interpretable as the within-field effect of being female. Of course, the standard form would be to include one control for the "effect of being female" along with a set of $n-1$ (e.g., six in the bachelor's degree analysis) interactions for "female*field of study." The interpretations of these interactions are differential (from the main effect of being female) within-field effects of being female, which greatly complicates their interpretation; in addition, the standard errors and, thus, tests of significance are for the differential not between men and women in a field, but between the main effect of being female (or the effect of being female in the omitted field) and the effect of being female in the field of interest.

I use weekly earnings rather than annual earnings in order to account for differences in weeks worked, and weekly earnings with control for logged hours worked per week, rather than hourly earnings in order to allow the return to hours worked per week to differ from one. I use a three-part spline function for the logged hours worked per week control. The three spline regions correspond to part time (20-32 hours/week), full time (33-50 hours/week), and full time plus (more than 50 hours/week). This further allows the return to hours to vary by number of hours worked, in recognition of the institutional fact that, while professionals working part time may be paid by the hour, many full-time professionals are salaried rather than paid by the hour. Allowing the return to hours to vary is an important methodological consideration in estimating gender pay differentials, since men and women tend to be differently distributed across hours worked. To the extent men work longer hours than women; overestimating the return to hours necessarily underestimates the penalty to women (see Morgan and Arthur 2005 for a complete discussion).

Other controls include full- and part-time experience, in years, and squared terms for each.

I use three variables to proxy for "jobs": occupation (and occupation*industry for management occupations in the bachelor's degree analysis), industry, and organization type. This differs somewhat from common terminology, 
where job is treated as either the combination of detailed occupation and employer (or establishment) or as occupation alone. For occupation controls, I use a total of 116 dummy variables for bachelor's degree analyses and 114 dummy variables for graduate degree analyses. These dummy variables are constructed as follows. First, I use two-digit occupations for occupations containing fewer than 5 percent of the individuals in these data. For occupations containing 5 percent or more of the individuals in these data, I used the more detailed three-digit breakdown. I do this instead of using the complete three-digit classification in order to capitalize on the occupational detail available in these data, while not making analysis unnecessarily complicated. At the three-digit level, many of the occupations in the remaining group are held by only one or two individuals in the sample. A complete set of three-digit occupation controls would be a total of almost 500 dummy variables for both bachelor's and graduate degree analyses. In addition, for the bachelor's degree analyses, I add a set of dummy variables corresponding to the combination of detailed occupation and industry, for managerial occupations, ${ }^{13}$ since the occupational breakdown is notoriously crude for these jobs (Jacobs 1992). This is also in keeping with Petersen and Morgan (1995), who find that jobs, the combination of detailed occupation and employer, explain the gender pay gap. The occupation*industry dummies are not included in the graduate degree analyses, as there are far fewer cases with which to work (about 2800 versus about 8400 for the bachelor's degree analyses).

Along with occupation, I also add control for industry (118 dummy variables for bachelor's degree analyses; 97 dummies for the graduate degree analysis), with dummy variables constructed in the same way as for occupation; I use broader categories for industries where fewer than 5 percent of individuals work; and detailed classification for industry categories containing 5 percent or more of individuals in these data. Control for organization type (five dummy variables) is also included since women tend to be overrepresented in lower-paying establishments as well as in lower-paying occupations (Petersen and Morgan 1995), also theorized to be the result of demand-side processes (England 1992).

All models include control for disabled, and non-U.S. citizen, and race, since these may be axes of discrimination. ${ }^{14}$

\footnotetext{
${ }^{13}$ This covers a total of fourteen detailed occupations. About 600 of the 8439 individuals in the bachelor's degree analysis work in one of these fourteen occupations; over half of these in one of three occupations: "managers, service organizations, n.e.c.," "managers, other organizations, n.e.c.," or "managers, sales organizations." Adding the industry interaction provides additional detail.

${ }^{14}$ I do not include control for children because when controlling for experience in these models, the effects of children are virtually zero.
} 


\section{2 / Laurie A. Morgan}

In order to address Hypotheses 1, I estimate equation (1) without the "job" controls-occupation, employer industry, and employer organization type. As discussed above, the coefficients of interactions between female and major field of study are the estimates of within-field gender pay differentials. Other human capital controls, including work experience and hours/week worked (logged), are included in these models. In order to address Hypothesis 2, job controls are added; the resulting changes in estimates of the female*major field of study interactions from the model without job controls can be attributed to jobs. Specifically, if women as compared to men in the same major field of study are concentrated in lower-paying jobs, the addition of jobs controls to the model will reduce within-major estimates from the model without job controls. We can interpret the size of the change in absolute terms or as the proportion of the base penalty explained by the control.

In order to determine the extent to which major accounts for the overall gender pay gap, the vector of female*major field of study interactions is replaced with a single variable, female. The model is estimated with hours/ week controls (and race, disabled, and noncitizen controls) to give a base estimate of the effect of being female. Controls for experience, major field of study, and jobs are added one at a time, in order to determine the extent to which women's distribution on each of those factors accounts for the base penalty.

\section{Results and Discussion}

Table 2 addresses Hypothesis 1a versus Hypothesis 2a, whether or not within-major gender pay differentials are zero. Panel A contains results for bachelor's degree graduates; Panel B contains results for graduate degree holders.

The first column gives percentage of female for each of the fields listed; the second column contains the total weighted $N$ for each of the fields listed; the third column contains within-major estimates of the effect of being female; and the fourth column gives within-major estimates adding controls for jobs: occupations, organization type, and industry. Results presented in Column 3 of Panel A show that within-major pay penalties are virtually zero for the professional fields (engineering and architecture; nursing, health, and biological sciences; and education), as well as mathematical, physical, and computer sciences, for those whose highest degrees are bachelor's. Not only are these estimates very small, none are statistically significant. Within-major pay penalties are much larger for two bachelor's degree majors: business administration, where the effect of female on logged 
TABLE 2

Ordinary Least-Squares Estimates of Within-Major Effects of being Female on 1989 ln(Weekly Earnings) a 1984-1988 Graduates; Data from the 1993 National Survey of College Graduates AND Appended 1990 Census (Individuals Working 20 Hours/Week or More AND More than 26 WeEKS IN 1989)

Panel A: Highest degree $=$ Bachelor's

\begin{tabular}{|c|c|c|c|c|}
\hline \multirow[b]{2}{*}{ Majors in: } & \multirow[b]{2}{*}{$\begin{array}{l}\text { (1) } \\
\text { Percent female }\end{array}$} & \multirow[b]{2}{*}{$\begin{array}{c}(2) \\
\text { Weighted } N\end{array}$} & \multicolumn{2}{|r|}{ Effect of being female } \\
\hline & & & $\begin{array}{c}(3) \\
\text { Base }^{b}\end{array}$ & Add: control for job characteristics \\
\hline Engineering and architecture & 16.4 & 195,710 & -0.009 & 0.005 \\
\hline Mathematics, computer, and physical sciences & 35.2 & 146,260 & 0.036 & 0.022 \\
\hline Accounting & 55.4 & 129,120 & -0.026 & -0.020 \\
\hline Business administration (other than accounting) & 47.9 & 406,720 & $-0.106^{* * *}$ & $-0.063^{* *}$ \\
\hline Social sciences, history, and humanities & 60.4 & 389,320 & $-0.086 * * *$ & -0.039 \\
\hline Nursing, health professions, and biological sciences & 72.7 & 164,520 & 0.035 & -0.018 \\
\hline Education & 76.0 & 115,840 & 0.002 & 0.015 \\
\hline Overall & 51.2 & $1,547,500$ & $-0.051 * * *$ & $-0.028 *$ \\
\hline
\end{tabular}

Panel B: Highest degree $=$ Master's, Doctorate, or Professional

\begin{tabular}{|c|c|c|c|c|}
\hline \multirow[b]{2}{*}{ Majors in: } & \multirow[b]{2}{*}{$\begin{array}{c}\text { (1) } \\
\text { Percent female }\end{array}$} & \multirow[b]{2}{*}{$\begin{array}{c}(2) \\
\text { Weighted } N\end{array}$} & \multicolumn{2}{|r|}{ Effect of being female } \\
\hline & & & $\begin{array}{l}(3) \\
\text { Base }\end{array}$ & Add: control for job characteristics \\
\hline Traditionally male fields ${ }^{\mathrm{d}}$ & 21.3 & 73,677 & -0.039 & -0.035 \\
\hline Professional fields ${ }^{\mathrm{e}}$ & 38.4 & 156,090 & -0.028 & 0.003 \\
\hline Social sciences, history, and humanities & 57.1 & 78,393 & 0.017 & 0.026 \\
\hline Traditionally female fields ${ }^{\mathrm{f}}$ & 75.0 & 124,220 & -0.025 & -0.047 \\
\hline Overall & 49.4 & 432,950 & -0.019 & -0.010 \\
\hline
\end{tabular}

432,950

Notes:

$* * *, * *$, and $*$ denote significance at the $0.001,0.01$, and 0.05 level, respectively.

apooled data within degree groups: bachelor's and graduate.

${ }^{b}$ Includes control for ln(hours worked/week), three-part spline; years of full-time and part-time work experience (and squared terms); race (five categories); disability; noncitizen, along with main effect of major (one category omitted).

${ }^{c}$ Adds controls for occupation, organization type, and industry. Also, for bachelor graduates only, adds control for interaction between occupation and industry for management occupations.

Includes engineering, architecture, math, physical sciences, and computer sciences.

'Includes business (MBA), law (JD), and medicine (MD).

fIncludes nursing, health, biological sciences, and education. 


\section{4 / Laurie A. Morgan}

earnings is -0.106 , and social sciences, history, and humanities, where the effect is -0.086 . Both are statistically significant at $p<0.001$ (two-tailed). Results presented in Column 4 of Panel A show that jobs account for a substantial portion of the within-major gender pay penalties for these two majors, the effect of being female is reduced to $-0.063(p<0.01)$ for business administration, and to -0.039 (not significant) for social sciences, history, and humanities.

Results for those who hold graduate degrees (Panel B, column 3) show that within-major gender pay differentials are virtually zero for all fields, and none are statistically significant. The addition of jobs controls (Panel $\mathrm{B}$, column 4) makes no real difference in these results.

Interestingly, I find no pattern of women's disadvantage in traditionally (or predominately) male fields, as would be predicted by Kanter (1977). ${ }^{15}$ While business administration was a traditionally male field, as I discuss above, these data indicate that among those whose highest degree is a bachelor's, almost half are women (47.9 percent). In addition, I find no advantage of men in traditionally female fields (for example, nursing and health majors, or education). In fact, men's advantage/women's disadvantage comes in the two bachelor's degree general studies fields - social sciences, history and humanities, and business administration (except accounting). And for both of these groups of majors, women's disadvantage is substantially explained by jobs, with women working in lower-paying ones. These findings are consistent with Hypothesis 3; within-major gaps are small for those in professional majors among bachelor's degree graduates and for graduate degree majors, and larger for those in general studies bachelor's degree majors, where it appears that women are sorted into lower-paying jobs in the labor market.

Table 3 contains results that follow from Hypotheses $1 b, 2 b$, and $3 b$, addressing the question of the extent to which college major accounts for the overall gender pay gap for these early career individuals. Here the goal is not to address within-field gender pay differentials but to produce a standard accounting of the extent to which (1) work experience, (2) college major, and finally (3) job characteristics, in succession account for the overall gender pay differential among these college graduates. The change in the "effect of being female" as various controls are added to the model can be interpreted as the amount of the original effect "explained" by those controls.

Column 1 contains estimates of the coefficient of female with various sets of controls for those whose highest degree is a bachelor's; Column 2 contains the same estimates for those who hold graduate degrees. The base model

\footnotetext{
${ }^{15}$ For a more recent study, see also Budig (2002).
} 
TABLE 3

OrdinARY LEAST-SQUAREs Estimates of THE EFFECT OF BEING

FEMALE ON 1989 LN(WEEKLy EARNINGS) ${ }^{\mathrm{a}}$

1984-1988 Graduates; Data from the 1993 National Survey of College Graduates and Appended 1990 Census (Individuals Working 20 Hours/Week or More and More than 26 WEEKS IN 1989)

\begin{tabular}{lcc}
\hline \hline & \multicolumn{2}{c}{ Effect of being female } \\
\cline { 2 - 3 } & \multicolumn{1}{c}{$(1)$} & $(2)$ \\
With control for: & Highest degree $=$ bachelor's & Highest degree $=$ graduate \\
\hline Raw: control for hours/week $^{\mathrm{b}}$ & $-0.129^{* * *}$ & $-0.095^{* * *}$ \\
Add: work experience $^{\mathrm{c}}$ & $-0.100^{* * *}$ & $-0.088^{* * *}$ \\
Add: college major & $-0.051^{* * *}$ & -0.019 \\
Add: job characteristics & $-0.028^{*}$ & -0.010 \\
Sample: & & 2798 \\
$\quad N$ & 8439 & 1190 \\
$N$ (female) & 3736 & 432,950 \\
Weighted: & & 213,850 \\
$N$ & $1,547,500$ & \\
$N$ (female) & 792,600 &
\end{tabular}

Notes:

$* * *, * *$, and $*$ denote significance at the $0.001,0.01$, and 0.05 level, respectively.

aPooled regressions for each degree group: bachelor's and graduate.

${ }^{b}$ Includes control for $\ln$ (hours worked/week), three-part spline; race (five categories); disability; noncitizen.

${ }^{\mathrm{c}}$ Includes control for $\ln$ (hours worked/week), three-part spline; years of full-time and part-time work experience (and squared terms); race (five categories); disability; noncitizen.

${ }^{\mathrm{d}}$ For bachelor's degree analysis, major includes seven categories: engineering and architecture; mathematics, computer, and physical sciences; accounting; business administration (except accounting); social sciences, history, and humanities; nursing, health technology, and biological sciences; and education. For graduate degree analysis, accounting is combined with business (MBA), and law and medicine are added, for a total of eight categories.

e"Job characteristics" includes occupation; organization type; and industry. For bachelor's degree graduates, an interaction between occupation and industry is added for managerial occupations.

controls only for hours worked (three-part spline), so that results are comparable to those using wage as the dependent variable. It reflects a smaller penalty to women than in the raw descriptives (Table 1) because, on average, women work fewer hours/week than men. The base model also controls for race, disabled, and noncitizen. For those whose highest degree is a bachelor's, this base penalty to female is -0.129 . The addition of experience terms (full time, part time, and squared terms for each) reduces the penalty to -0.100 . The addition of major field of study reduces the penalty substantially to -0.051 . Finally, the addition of job controls reduces the penalty to female to -0.025 . These findings are consistent with those just discussed and with Hypothesis 3; within-major gaps are very small for several majors and larger for others, which happen to be majors in which many women are concentrated, and with these larger gaps accounted for by jobs. In the aggregate then, to the extent women are concentrated in the majors where 


\section{6 / Laurie A. Morgan}

they face large penalties (social sciences, history, and humanities, and business administration (except accounting)), majors do not completely account for the overall gender pay differential, and jobs explain a portion of the differential that remains after controlling for major.

Among those who hold graduate degrees, the base penalty to female is -0.095 . The addition of experience (full and part time) accounts for virtually none of that; the penalty with these controls is -0.088 . The addition of major field of study and highest degree level reduces the penalty virtually to zero ( -0.019 ; not statistically significant). Jobs account for little beyond education, as there is little left to explain. These results are consistent with Hypotheses 1 and 3.

\section{Conclusion}

I use data from the 1993 NSCG and appended 1990 Census on about 11,000 men and women to address questions regarding the link between college major and thus gender pay differentials. This study offers new insight along several dimensions. It is the first such analysis to focus on within-major differences in outcomes, which is crucial in assessing whether women gain similar rewards to men for a particular major field of study. First, I find that women fare better relative to men in bachelor's degree professional majors and graduate degree majors, and theorize that this is because these majors have tighter links to jobs. The finding is somewhat encouraging, as it suggests that these women at least reap the same rewards from their degrees as do comparably trained men; their "supply-side" decisions pay off. Most notably, these results suggest that efforts to encourage women to enter engineering and mathematics and physical sciences are well-advised. Contrary to some expectations that these would be the areas most hostile to women, I find that women, in the early career stage at least, are on an equal footing with men. On the other hand, the findings are discouraging to the extent that they show large earnings penalties to women (at the bachelor's level) in two key general studies fields - social sciences, history, and humanities, and business administration - where evidence that jobs account for a large portion of these penalties suggests that women are sorted into lower-paying jobs than similarly trained men. This pattern is particularly troubling given the focus here on early-career outcomes. We have no reason to expect that these differentials will narrow over the course of these women's work careers; on the contrary, other evidence suggests that this disadvantage will only grow.

Whether this is a matter of employer discrimination, or further posteducational supply-side processes, is an open question, and one that calls for 
further investigation. Findings can be viewed as consistent with intentional discrimination described by Petersen and Saporta (2004), where employers discriminate against women to the extent they can. Discriminating against women who have clear professional credentials may be more costly than discriminating against women with general studies degrees, because it is much easier to identify comparable men. Findings can also be viewed as consistent with the unconscious bias mechanism for employer discrimination described by Reskin (2000). Perhaps a professional degree (for example, in engineering) provides the kind of objective information Reskin (2000) argues is necessary to overcome unconscious bias, whereas employers rely more on subjective assessments of general studies degree graduates. In either case, to the extent general studies graduates have less clear career plans than those who pursue professional majors, both of these mechanisms of employer discrimination should operate more vigorously. Alternatively of course, these patterns may be the result of further posteducational supplyside processes; for example, gender differences in preferences for different kinds of work or working conditions. And of course, there is always the possibility that these patterns are the result of unobserved heterogeneity, which should be taken seriously because of the extreme imbalance in the numbers of women versus men earning bachelor's degrees. This also is an area in need of further study.

Second, consistent with the findings that within-major gender pay differentials are small for some majors, and that jobs account for most of the penalties within majors where they are larger, I find that majors account for about 40 percent of the raw pay gap (reduces the effect after control for work experience from -0.100 to -0.051 ) for those whose highest degree is a bachelor's, and for about 70 percent of the raw pay gap (reduces the effect after control for experience from -0.088 to -0.019 ) for those who hold graduate degrees. Jobs account for an additional, although small, increment for the bachelor's degree graduates - about 20 percent - owing to their role in explaining the larger within major penalties for business administration (except accounting) and social sciences, history, and humanities majors in which many women are concentrated. I conclude that among college graduates, women's occupational disadvantage relative to men is determined primarily in college through the choice of major field of study, not from a disproportionate tendency to exit to other (lower-paying) occupations. These findings suggest that we further focus our attention on both the "supply side" and "demand side" in understanding segregation and gender pay inequality, and that in the absence of a restructuring of occupational rewards, women must achieve parity in college majors in order to attain parity in occupations, and thus pay with men. 


\section{8 / LAUrie A. Morgan}

My findings suggest that pay penalties to women in the aggregate can be traced to relatively large penalties in a couple of key fields (bachelor's degree-level general studies fields): social sciences and humanities, and business administration (except accounting). These findings are important, as they contradict the prevailing view. Existing empirical research suggests that field of study explains little or none of the gender gap in pay (Brown and Corcoran 1997; Marini and Fan 1997). However, as I discussed earlier, these studies collapse individuals across majors ${ }^{16}$ and, thus, imply that women are uniformly disadvantaged compared to men regardless of field of study. I find no evidence of early-career pay penalties to women within professional fields at the bachelor's degree level, or within any field at the graduate degree level.

A final note about the focus on early-career individuals: we do not know whether these women will face glass ceilings in their careers. Findings from case studies of specific professions have produced mixed results. For example, Morgan (1998) finds evidence of a cohort effect, where gender pay penalties for younger cohorts are zero for younger cohorts and do not increase over time, but no evidence of a glass ceiling. On the other hand, in the studies of lawyers, Wood, Corcoran, and Courant (1993) find gender pay penalties that are small at career entry, but grow with experience, even among relatively recent cohorts of graduates. Sorting this out will require longitudinal data across fields. Unfortunately, the National Science Foundation followed up only the scientists and engineers from the 1993 NSCG. On the other hand, as I argued earlier though, a finding of small early-career gender pay penalties may be read as encouraging news, since we have little reason to expect that within-cohort differentials will improve with time.

\section{REFERENCES}

American Association of University Women. 1991. Shortchanging Girls, Shortchanging America. Washington, DC: AAUW.

Bielby, William T., and James N. Baron. 1984. "A Woman's Place Is with Other Women: Sex Segregation within Organizations." In Sex Segregation in the Workplace: Trends, Explanations, Remedies, edited by Barbara Reskin, pp. 27-55. Washington, DC: National Academy Press.

Blau, Francine D. 1998. "Trends in the Well-being of American Women, 1970-1995." Journal of Economic Literature 36(March):112-65.

_ Marianne A. Ferber, and Anne E. Winkler. 2002. The Economics of Men, Women, and Work. Upper Saddle River, NJ: Prentice Hall.

Brown, Charles, and Mary Corcoran. 1997. "Sex-Based Differences in School Content and the Male-Female Wage Gap.” Journal of Labor Economics 15(3, Part 1):431-65.

Budig, Michelle J. 2002. "Male Advantage and the Gender Composition of Jobs: Who Rides the Glass Escalator?" Social Problems 49(2):258-77.

\footnotetext{
${ }^{16}$ And, in the case of Marini and Fan (1997), pool college and high school graduates.
} 


\section{Within-Major Gender Pay Gap}

Collins, Sharon M. 1997. Black Corporate Executives: The Making and Breaking of a Black Middle Class. Philadelphia: Temple University Press.

Corcoran, Mary, and Greg Duncan. 1979. "Work History, Labor Force Attachments, and Earnings Differences between the Races and Sexes." Journal of Human Resources 14(1):3-20.

Daymont, Thomas N., and Paul J. Andrisani. 1984. "Job Preferences, College Major, and the Gender Gap in Earnings." Journal of Human Resources 19(3):408-28.

England, Paula. 1992. Comparable Worth: Theories and Evidence. New York: Aldine de Gruyter.

—, and Su Li. 2006. "Desegregation Stalled: The Changing Gender Composition of College Majors, 1971-2002." Gender \& Society 20(5):657-77.

, George Farkas, Barbara Stanek Kilbourne, and Thomas Dou. 1988. "Explaining Occupational Sex Segregation and Wages: Findings from a Model with Fixed Effects." American Sociological Review 53(4):544-58.

Greenberger, Marcia. 2002. "Testimony Before the Subcommittee on Science, Technology, and Space of the Senate Committee on Commerce, Science, and Transportation: Title IX and the Sciences." October 3, 2002.

Jacobs, Jerry. 1989. Revolving Doors: Sex Segregation and Women's Careers. Stanford, CA: Stanford University Press.

. 1992. "Women's Entry into Management: Trends in Earnings, Authority, and Values among Salaried Managers.” Administrative Science Quarterly 37(2):282-301.

. 1995. "Gender and Academic Specialties: Trends among Recipients of College Degrees in the 1980s." Sociology of Education 68(2):81-98.

. 2001. "Evolving Patterns of Sex Segregation." In Sourcebook of Labor Markets: Evolving Structures and Processes, edited by Ivar Berg and Arne L. Kalleberg. pp. 535-50. New York: Kluwer Academic/Plenum.

Joy, Lois. 2000. "Do Colleges Shortchange Women? Gender Differences in the Transition from College to Work." AEA Papers and Proceedings 90(2):471-5.

Kanter, Rosabeth Moss. 1977. Men and Women of the Corporation. New York: Basic Books.

Kessler-Harris, Alice. 1982. Out-to-Work: A History of Wage-Earning Women in the United States. Oxford: Oxford University Press.

Kleinfeld, Judith. 1998. "Why Smart People Believe that Schools Shortchange Girls: What You See When You Live in a Tail." Gender Issues 16(1/2):47-63.

Marini, Margaret M., and Mary C. Brinton. 1984. "Sex Typing in Occupational Socialization." In Sex Segregation in the Workplace: Trends, Explanations, Remedies, edited by Barbara Reskin, pp. 192234. Washington, DC: National Academy Press.

_ Review 62(4):588-604.

Morgan, Laurie A. 1998. "Glass Ceiling Effect or Cohort Effect? A Longitudinal Study of the Gender Earnings Gap for Engineers, 1982-1989." American Sociological Review 63(4):479-93.

_ _ and Michelle M. Arthur. 2005. "Methodological Considerations in Estimating the Gender Pay Gap for Professionals." Sociological Methods and Research 33(3):383-403.

National Center for Education Statistics. 2003. Digest of Education Statistics, 2002. NCES 2003-060 (by Thomas D. Snyder. Production Manager, Charlene M. Hoffman). Washington, DC: U.S. Department of Education.

National Science Foundation. 1993. Survey of College Graduates. Arlington, VA: National Science Foundation.

Paglin, Morton, and Anthony M. Rufolo. 1990. "Heterogeneous Human Capital, Occupational Choice, and Male-Female Earnings Differences.” Journal of Labor Economics 8(1, Part 1):123-44.

Petersen, Trond. 1989. "The Earnings Function in Sociological Studies of Earnings Determination: Functional Form and Hours Worked." Research in Social Stratification and Mobility 8: 220-49.

_ and Ishak Saporta. 2004. "The Opportunity Structure for Discrimination." American Journal of Sociology 109(4):852-901.

_ and the Gender Wage Gap." American Journal of Sociology 101(2):329-65. 


\section{0 / Laurie A. Morgan}

Polachek, Solomon. 1979. "Occupational Segregation among Women: Theory, Evidence, and a Prognosis." In Women in the Labor Market, edited by Cynthia B. Lloyd, Emily S. Andrews, and Curtis L. Gilroy, pp. 137-57. New York: Columbia University Press.

Reskin, Barbara. 1993. "Sex Segregation in the Workplace." Annual Review of Sociology 19:241-70.

. 2000. "The Proximate Causes of Employment Discrimination." Contemporary Sociology 29(2):319-28.

Sadker, Myra, and David Sadker. 1994. Failing at Fairness: How America's Schools Cheat Girls. New York: Scribners.

Stoops, Nicole. 2004. Educational Attainment in the United States: 2003. Population Characteristics. Washington, DC: U.S. Census Bureau, U.S. Department of Commerce, Economics and Statistics Administration.

U.S. Census Bureau. 2002. Current Population Survey, 4th quarter, 2002. Washington, DC: U.S. Census Bureau.

U.S. Congress. House. Committee on Science. Subcommittee on Technology. 2000. A Review of the Morella Commission Report: Recommendations to Attract More Women and Minorities into Science, Engineering, and Technology: Hearing Before the Subcommittee on Technology of the Committee on Science, House of Representatives, One Hundred Sixth Congress, second session, July 13, 2000.ress. House. Washington DC: U.S. Government Printing Office.

Valian, Virginia. 1998. Why So Slow? The Advancement of Women. Cambridge, MA: MIT Press.

Wellington, Alison. 1993. "Changes in the Male/Female Wage Gap, 1976-85." Journal of Human Resources 28(2):383-411.

Williams, Christine. 1989. Gender Differences at Work. Berkeley, CA: University of California Press.

Women's Bureau, U.S. Department of Labor. 1993. Women Workers: Trends \& Issues, 1993 Handbook. Washington, DC: U.S. Department of Labor.

Wood, Robert G., Mary E. Corcoran, and Paul N. Courant. 1993. "Pay Differences among the Highly Paid: The Male-Female Earnings Gap in Lawyers' Salaries." Journal of Labor Economics 11(3):417-41. 